\title{
Effect of feeding fresh or conditioned red clover on milk fatty acids and nitrogen utilization in lactating dairy cows
}

\author{
M. R. F. Lee, ${ }^{1}$ V. J. Theobald, J. K. S. Tweed, A. L. Winters, and N. D. Scollan \\ Institute of Biological, Environmental and Rural Sciences, Aberystwyth University, Gogerddan, Aberystwyth, SY23 3EB, United Kingdom
}

\begin{abstract}
Polyphenol oxidase (PPO) in conditioned red clover (ensiled or cut and crushed) reduces both proteolysis and lipolysis in the herbage, which has led to increases in $\mathrm{N}$ use efficiency and polyunsaturated fatty acid (PUFA) content of milk when offered to dairy cows. In damaged plant cells, PPO is activated and binds protein through the formation of protein-bound phenols. This study investigated a) whether freshly cut red clover could increase N use efficiency and milk PUFA concentrations in dairy cows or whether PPO enzymes require prior activation before feeding to elicit a response, and b) apparent whole-tract amino acid digestibility to help determine the effect of PPO on amino acid utilization. Six multiparous Holstein $\times$ Friesian dairy cows in midlactation were allocated at random to 1 of 3 dietary treatments in a $3 \times 3$ Latin square: a control treatment of grass (low PPO, G); red clover (high PPO, RC), and conditioned red clover (high fully activated PPO, CRC). The CRC herbage was cut and chopped in the field and then transported with the $\mathrm{G}$ and $\mathrm{RC}$ herbages to the animal house. Each period consisted of a 2-wk adaptation to diet and a week of measuring dietary effects ( $\mathrm{N}$ balance and milk collection). The PPO activity was greatest in the RC treatment as fed, whereas activation of latent PPO enzyme and protein-bound phenol levels were greatest in the CRC diet. Dry matter and total fatty acid intakes were comparable across treatments $(18.8 \mathrm{~kg} / \mathrm{d}$ and $550 \mathrm{~g} / \mathrm{d}$, respectively). Milk yields and total fatty acid content were similar across treatments $(32.6 \mathrm{~kg} / \mathrm{d}$ and $34.8 \mathrm{mg} / \mathrm{mL}$, respectively). Cows offered either RC or CRC had greater levels of protein, C18 PUFA and total long-chain PUFA in their milk than animals offered grass with no difference between RC and CRC. Nitrogen intakes, and output in milk, urine, and feces were greater in cows offered the 2 red
\end{abstract}

Received September 8, 2008.

Accepted October 21, 2008.

${ }^{1}$ Corresponding author: michael.lee@aber.ac.uk clover treatments than $\mathrm{G}$, with no difference between $\mathrm{RC}$ and CRC. However, there were no differences in $\mathrm{N}$ use efficiency among diets as measured by the proportion of feed $\mathrm{N}$ converted into milk $\mathrm{N}$, possibly as the result of the excessive supply of $\mathrm{N}$ with the red clover diets. Amino acid apparent whole-tract digestibilities were greater when on RC than G diets and intermediate when on CRC for all amino acids, with the exception of Met, which was reduced in cows on both red clover diets compared with G. It is proposed that the PPO trait could show more benefit to ruminants if red clover was fed in combination with lesser $\mathrm{N}$-containing forages or if red clover was bred to contain less $\mathrm{N}$.

Key words: red clover, polyphenol oxidase, $\mathrm{N}$ use efficiency, polyunsaturated fatty acid

\section{INTRODUCTION}

The rate of proteolysis of forage proteins in the rumen is a key determinant of the efficiency of conversion of feed $\mathrm{N}$ into products or pollutants. The efficiency of conversion of feed $\mathrm{N}$ into milk (20 to $30 \%$ ) or meat (10 to $20 \%$ ) by ruminants is often well below potential $(>40 \%)$, and is particularly minimal with diets based on poor quality grass silages (Dewhurst et al., 1996) or grazed herbage (Beever et al., 1986). At the same time, the biohydrogenation of fatty acids in the rumen following lipolysis of plant glycerol-based lipids reduces the polyunsaturated fatty acid (PUFA) to saturated fatty acid (SFA) ratio of both meat and milk. The feeding of red clover silage has been shown to reduce both $\mathrm{N}$ and PUFA losses when offered to dairy cows (Dewhurst et al., 2003). This is thought to be related to the enzyme polyphenol oxidase (PPO), which is associated with the browning losses in fruit and vegetables but has also been associated with reductions in both proteolysis and lipolysis both in the silo (Albrecht and Muck, 1991; Lee et al., 2008a) and the rumen (Albrecht and Broderick, 1992; Lee et al., 2007). This protection may be related to the formation of quinones produced by the PPOcatalyzed oxidation of vacuolar diphenols. The exact mechanism of the subsequent quinone-protein reaction is not fully understood. The amine group of free AA 
reacts with quinones forming phenols that are susceptible to further oxidation reactions (Rouet-Mayer et al., 1993). As peptides, certain side chains, namely amines (e.g., Lys, Rouet-Mayer et al., 1993; Akagawa et al., 2005) and sulfo (e.g., Met, Igarashi and Yasui, 1985; Rouet-Mayer et al., 1993), have been highlighted as potential targets of quinone attack, which, once bound, reform phenols covalently bound to the protein. The resultant phenol-bound protein complex reduces proteolysis and lipolysis in the silo through deactivation of plant proteases (Jones et al., 1995) and lipases (Lee et al., 2004). However, in the rumen plant enzymes are less active than the numerically superior microbial enzymes and subsequently proteolysis appears to be reduced due to the PPO-induced complexing of leaf proteins, reducing digestibility (Winters and Minchin, 2001). Lipolysis in the rumen is also reduced through the actions of PPO before ingestion (Lee et al., 2007), possibly as a consequence of entrapment of lipid micelles in the phenol-bound protein complex as postulated by Lee et al. (2008b).

Although the effect of PPO in red clover silage has been established, its role in grazed red clover is yet to be determined. Red clover PPO enzyme exists within the plant in both the active (approximately 10\%) and latent (approximately 90\%) forms; the former is active within the cell at neutral $\mathrm{pH}$, whereas the latter requires activation (Lee et al., 2008c). Conversion of the latent to the active form (activation) can occur in red clover plant tissue either through proteolytic activity or mixing with endogenous phenolic substrate (phaselic acid and clovamide; Winters et al., 2008). Activation is prevented in healthy tissue due to the compartmentalization of the enzyme (chloroplast) and substrate (vacuole). Therefore, for PPO activation and activity to occur, cell damage (mixing of enzyme and substrate and activating latent PPO) and aeration (supply of oxygen for the oxidation reaction) are required. These 2 criteria are easily met during silage making, but during grazing the anaerobic nature of the rumen provides only a small window of opportunity during mastication (cell damage and aeration) for PPO activation (Lee et al., 2008c).

The objectives of this study were to determine whether offering conditioned red clover versus freshly cut red clover, with grass used as a negative control, would result in an elevation in $\mathrm{N}$ use efficiency and milk PUFA content as a consequence of PPO activation. In addition, apparent whole-tract AA digestibilities were assessed to indicate the potential effects of phenol covalent binding to AA induced through PPO activity on their subsequent digestibility.

\section{MATERIALS AND METHODS}

\section{Experimental Design}

The experiment involved 6 multiparous Holstein $\times$ Friesian dairy cows in midlactation on 3 dietary treatments in a changeover-design experiment $(3 \times 3$ Latin square): 1) grass as the control $(\mathbf{G})$, low PPO; 2) red clover (RC), high PPO; and 3) conditioned (chopped, bruised) red clover (CRC), high PPO and activated latent PPO. Measurements included milk fatty acid profiles, $\mathrm{N}$ partitioning into milk, urine, and feces with forage intake, and apparent whole tract AA digestibility and fecal output.

\section{Diets and Allocation to Treatment}

Italian ryegrass (Lolium multiflorum) and red clover (Trifolium pratense) were sown in plots with approximate areas of 0.7 and 1.5 ha, respectively. Six multiparous Holstein $\times$ Friesian dairy cows $(650 \pm 34.8$ $\mathrm{kg}$ ) in midlactation (with similar milk yields and stage of pregnancy) were maintained on a grass silage diet before allocation to treatment and during a 1-wk covariate period. Mean milk yields were recorded during the covariate, and the 3 cows with the 3 greatest mean yields were allocated within a "high-yielding group" (cows 1 through 3 ), and the cows with the 3 least yields allocated within a "low-yielding group" (cows 4 through 6). Within each Latin square, the cows from each group were allocated at random to 1 of 3 treatments listed above (Cochran and Cox, 1957). Each period consisted of a 2-wk adaptation followed by a 1-wk measurement period.

\section{Feeding}

Four weeks before the commencement of the study, each forage plot was split into 4 subplots. Each of these 4 subplots was subsequently managed to provide sufficient forage at 4 weeks of regrowth to be zero grazed (cut and carried) for each week of the experiment. Fresh $\mathrm{G}$ and RC were harvested daily in the early afternoon using a plot harvester (Haldrop 1500, J. Haldrop, Løgstør, Denmark). The CRC treatment was cut using a circular mower and chopper and was left as a swath in the field for about $1 \mathrm{~h}$ before collection. All forages were cut to a height of $5 \mathrm{~cm}$ above soil level. The cut forages (about $350 \mathrm{~kg}$ of fresh matter for each treatment per day) were then transported from the field, and $80 \mathrm{~kg}$ was placed into each of 12 large weld mesh containers $(120 \times 80 \times 100 \mathrm{~cm}$, length $\times$ depth $\times$ height $)$, to give 4 baskets of each treatment. The CRC treatment was 
transferred to a blast freezer and kept at $-15^{\circ} \mathrm{C}$ for $2 \mathrm{~h}$ to fully activate latent PPO. It was then transferred to a refrigerator at $4^{\circ} \mathrm{C}$ along with the $\mathrm{G}$ and $\mathrm{RC}$ treatments. A short piece of perforated drainage tube was placed into the center of each basket to aid with the chilling of the forage to prevent overheating. Both morning (about $0900 \mathrm{~h}$ ) and afternoon (about $1600 \mathrm{~h}$ ) feeds were kept in the refrigerator $\left(4^{\circ} \mathrm{C}\right)$ before feeding. All animals had free access to water and mineralized salt licks (baby red horse lick, Rockies, Winsford, Cheshire, UK) and received $100 \mathrm{~g}$ of a mineral and vitamin premix (CCF Centenary Cow Phos, Clyndewen and Cardigan Farmers Ltd., Narberth, Ceredigion, UK; containing $\mathrm{Ca}, 15.6 \%$; Na, $6.0 \%$; $\mathrm{Mg}, 8.0 \%$; Co, 100 $\mathrm{mg} / \mathrm{kg} ; \mathrm{Mn}, 4,000 \mathrm{mg} / \mathrm{kg} ; \mathrm{Cu}, 3,000 \mathrm{mg} / \mathrm{kg} ; \mathrm{Zn}, 4,000$ $\mathrm{mg} / \mathrm{kg} ; \mathrm{I}, 400 \mathrm{mg} / \mathrm{kg} ;$ Se, $30 \mathrm{mg} / \mathrm{kg}$; vitamin A, 400,000 $\mathrm{IU} / \mathrm{kg}$; vitamin $\mathrm{D}_{3}, 75,000 \mathrm{IU} / \mathrm{kg}$; and vitamin E, 1,000 $\mathrm{IU} / \mathrm{kg}$ ) and enough fresh forage for the measurement of ad libitum intakes with refusals of at least $10 \%$ of the forage offered. Samples of forage taken as fed were collected for each feeding and bulked per day during the measurement week. Samples for PPO and phenol analysis were collected daily during the measurement period from material placed in front of the cows, frozen immediately in liquid $\mathrm{N}$, and kept frozen at $-80^{\circ} \mathrm{C}$ until analysis. At milking, each cow received $1.0 \mathrm{~kg}(2.0$ $\mathrm{kg} / \mathrm{d}$ ) of standard $18 \%$ protein dairy concentrate (containing rolled barley, sugar beet pellets, and soybean meal; Clynderwen and Cardigan Farmers Ltd.). The concentrate was subsampled daily and bulked across the measurement week for each period.

\section{Animal Measurements}

Animal measurements were concentrated in the third week of each period. Cow weights were recorded at the start of the experiment as well as at the beginning and end of each period (before changing treatments). Milk yield was recorded throughout the experiment. Milk from the last $2 \mathrm{~d}$ of each period (separate a.m. and p.m. samples) were collected in supplied collection tubes containing a preservative and submitted to National Milk Records (www.nmr.co.uk) for analysis of SCC, fat, protein, and lactose content. Additional milk samples from these milkings (frozen without preservative) were retained for fatty acid and $\mathrm{N}$ analysis.

Nitrogen balance was measured by collecting the total output of urine and feces from each animal using externally applied urine and feces separators for a period of $6 \mathrm{~d}$ (Ashton et al., 1998). Urine was preserved by acidification (using $900 \mathrm{~mL}$ of $2 M$ sulfuric acid for each daily collection), and subsamples (1\% of each daily collection) were collected each day, bulked, and stored at $4^{\circ} \mathrm{C}$ during the collection week before storage at $-20^{\circ} \mathrm{C}$ at the end of collection before analysis of N. Daily subsamples of feces $(5 \%$ of each daily collection) were collected after thorough mixing, bulked, and stored at $4^{\circ} \mathrm{C}$ during the collection week; a 500-g sample was subsequently frozen at $-20^{\circ} \mathrm{C}$, freeze-dried, and ground before analysis of $\mathrm{N}$ and total and free AA. Nitrogen balance was calculated as the mean quantity of $\mathrm{N}$ consumed over the measurement period minus the mean of total $\mathrm{N}$ excreted in urine and feces and $\mathrm{N}$ secreted in milk over the same period. No correction factors were imposed for losses of $\mathrm{N}$ through the breath, sweat, skin, and hair, which have been shown to be minimal (Brito et al., 2008).

\section{Forage Analysis}

Water-soluble carbohydrate (WSC) of the forages was determined spectrophotometrically using anthrone in sulfuric acid on a Technicon Autoanalyser (Technicon Corp., New York, NY; Thomas, 1977). Ash and (by mass difference) OM was analyzed by combusting the ground samples at $550^{\circ} \mathrm{C}$ for $6 \mathrm{~h}$ in a muffle furnace. Total $\mathrm{N}$ was determined by micro-Kjeldahl technique using Kjeltec equipment (Perstorp Analytical Ltd., Maidenhead, UK). Neutral detergent fiber was determined as described by Van Soest et al. (1991) using the Tecator Fibertec System equipment (Tecator Ltd., Bristol, Somerset, UK). For the PPO activity assay, plant tissue was extracted according to the method of Winters et al. (2003) and assayed according to the method of Robert et al. (1995). In brief, plant material (approximately $0.5 \mathrm{~g}$ of fresh weight) was extracted at $0^{\circ} \mathrm{C}$ in $2 \mathrm{~mL}$ of McIlvaine buffer $(\mathrm{pH} 7)$ containing $0.1 M$ ascorbic acid to inhibit PPO activity. Extracts were centrifuged at $15,000 \times g$ for $10 \mathrm{~min}$ at $4^{\circ} \mathrm{C}$ and the supernatant was retained and then desalted by applying to columns $(1.5 \times 6 \mathrm{~cm})$ containing bioGel P6DG (BioRad, Hertfordshire, UK) prepared in McIlvaine buffer $(\mathrm{pH} 7)$ and centrifuging at 2,500 $\times g$ for $6 \mathrm{~min}$ at $4^{\circ} \mathrm{C}$. Active PPO content was determined spectrophotometrically at $420 \mathrm{~nm}$ using $10 \mu \mathrm{L}$ of eluted fraction with $15 \mu \mathrm{L}$ of $0.001 \mathrm{~m} M$ copper sulfate, 10 $\mathrm{m} M$ methylcatechol, and $1.5 \mathrm{~mL}$ of McIlvaine buffer. Total PPO activity (active + latent) was calculated with the addition of $0.25 \%$ SDS in the McIlvaine buffer. One unit of enzyme (U) was defined as the amount of enzyme that produced 1 micromole of quinone per minute based on the absorption at $420 \mathrm{~nm}$ of a known concentration of quinones formed through the reaction of methylcatechol and sodium periodate (Alder and Magnusson, 1959) giving a conversion factor of $\mathrm{U}=$ $2.717 \times \Delta$ optical density. Activation $(\%)$ is a measure of the amount of total PPO that was active. Bound and soluble phenol analyses were carried out using a 
modified Lowry procedure described by Winters and Minchin (2005), which takes into account the variable response of diphenols with the Lowry assay and estimates the quantity of phenol-bound protein. Diphenols (chlorogenic acid, clovamide, and phaselic acid) were analyzed by reverse-phase HPLC as described by Winters et al. (2008). Total and individual AA were determined by HPLC after acid hydrolysis by Alta Bioscience (University of Birmingham, West Midlands, UK). Threonine and Ser were corrected for loss ( 5 and 10\%, respectively), whereas Trp, cysteic acid, and cystine were omitted due to degradation during acid hydrolysis. Fatty acids were extracted and methylated from 0.5 $\mathrm{g}$ of freeze-dried sample suspended in $2 \mathrm{~mL}$ of toluene containing $0.4 \mathrm{mg} / \mathrm{mL} \mathrm{C23:0} \mathrm{as} \mathrm{an} \mathrm{internal} \mathrm{standard.}$ The methylation mixture and conditions consisted of 3 $\mathrm{mL}$ of a mixture of freshly made acetyl chloride to 10 parts anhydrous methanol at $70^{\circ} \mathrm{C}$ for $2 \mathrm{~h}$ (Sukhija and Palmquist, 1988). Fatty acid methyl esters (FAME) were analyzed by GLC on a CP-Select column chemically bonded for FAME $(100 \mathrm{~m} \times 0.25 \mathrm{~mm}$ ID, Varian Inc., Palo Alto, CA) with split injection (30:1) and $\mathrm{He}$ as the carrier gas with oven conditions and run time as described by Lee et al. (2005). Identification of fatty acids was performed using external standards (ME61, Larodan Fine Chemicals, Malmo, Sweden; S37, Supelco, Poole, Dorset, UK; conjugated linoleic acids, Matreya, Philadelphia, PA) and quantified using the internal standard (C23:0).

\section{Milk Analysis}

Milk N was analyzed using the Leco FP-428 nitrogen determinator (Leco Corp., Laurel, NJ) following instructions of the manufacturer. Fatty acids were extracted and methylated from $1 \mathrm{~mL}$ of milk. The milk was freeze-dried and then extracted in $1 \mathrm{~mL}$ of n-heptane containing $1 \mathrm{mg}$ of $\mathrm{C} 23: 0$ as internal standard. The methylation mixture and conditions consisted $4 \mathrm{~mL}$ of $\mathrm{NaOH}$ in methanol $(0.5 \mathrm{M})$ at $50^{\circ} \mathrm{C}$ for 15 min (Lee and Tweed, 2008). The obtained FAME were analyzed as described for forage fatty acids via GLC.

\section{Urine and Feces Analysis}

Urinary $\mathrm{N}$ was assessed as described for milk $\mathrm{N}$. Fecal $\mathrm{N}$, and total and individual AA were assessed as described for forage. Free AA in the feces were determined from an aqueous extract of freeze-dried material and analyzed with a Phenomenex EZ:faast free AA kit (for GC-FID, Phenomenex Inc., Torrance, CA). Using this procedure it was impossible to analyze for Arg because of its polar nature after derivatization and its subsequent adherence to the GC liner.

\section{Statistical Analysis}

All data were analyzed using a general ANOVA with $\operatorname{diet}$ ( $\mathrm{G}$ vs. RC vs. CRC) as the treatment effect and blocking according to animal (high-yielding group + low-yielding group $)+$ period $(1+2+3)$. All operations were performed using Genstat Release 10.2 (PC Windows, 2007, Lawes Agricultural Trust, Experimental Station, Rothamsted, UK).

\section{RESULTS}

\section{Forage Chemical Composition and Fatty Acid Intake}

Chemical compositions of the 3 forages as fed are given in Table 1. Dry matter, WSC, and NDF were greater in $\mathrm{G}$ than in either $\mathrm{RC}$ or $\mathrm{CRC}$, whereas the

Table 1. Chemical composition, polyphenol oxidase (PPO) activity, and o-diphenol concentrations in the forages ${ }^{1}$

\begin{tabular}{|c|c|c|c|c|c|}
\hline Item & G & $\mathrm{RC}$ & $\mathrm{CRC}$ & $\mathrm{SED}^{2}$ & $P$-value \\
\hline $\mathrm{DM}(\mathrm{g} / \mathrm{kg})$ & $160^{\mathrm{b}}$ & $139^{\mathrm{a}}$ & $145^{\mathrm{a}}$ & 6.0 & $* *$ \\
\hline $\mathrm{OM}$ & 905 & 904 & 904 & 6.89 & NS \\
\hline Water-soluble carbohydrate & $223^{\mathrm{b}}$ & $109^{\mathrm{a}}$ & $105^{\mathrm{a}}$ & 28.0 & ** \\
\hline Total N & $22.1^{\mathrm{b}}$ & $32.6^{\mathrm{a}}$ & $33.1^{\mathrm{a}}$ & 4.69 & $\dagger$ \\
\hline NDF & $441^{\mathrm{b}}$ & $309^{\mathrm{a}}$ & $320^{\mathrm{a}}$ & 37.0 & * \\
\hline PPO activity (U/g of DM) & $17.2^{\mathrm{a}}$ & $158^{\mathrm{b}}$ & $22.1^{\mathrm{a}}$ & 31.1 & $* * *$ \\
\hline PPO activation (\%) & $100^{\mathrm{b}}$ & $29.1^{\mathrm{a}}$ & $100^{\mathrm{b}}$ & 4.84 & $* * *$ \\
\hline Bound phenol & $1.72^{\mathrm{a}}$ & $5.48^{\mathrm{b}}$ & $10.5^{\mathrm{c}}$ & 1.612 & $* * *$ \\
\hline Soluble phenol & $37.0^{\mathrm{a}}$ & $90.4^{\mathrm{c}}$ & $68.9^{\mathrm{b}}$ & 5.78 & $* * *$ \\
\hline Phaselic acid $(\mu \mathrm{g} / \mathrm{g}$ of $\mathrm{DM})$ & - & $1,922^{\mathrm{b}}$ & $119^{\mathrm{a}}$ & 102.1 & $* * *$ \\
\hline Clovamide $(\mu \mathrm{g} / \mathrm{g}$ of $\mathrm{DM})$ & - & 117 & - & 20.8 & - \\
\hline Chlorogenic acid ( $\mu \mathrm{g} / \mathrm{g}$ of $\mathrm{DM})$ & 125 & - & - & 32.8 & - \\
\hline
\end{tabular}


LEE ET AL.

Table 2. Fatty acid compositions $(\mathrm{g} / \mathrm{kg}$ of $\mathrm{DM})$ of the dietary forages and concentrate ${ }^{1}$

\begin{tabular}{lcccccl}
\hline Fatty acid & $\mathrm{G}$ & $\mathrm{RC}$ & $\mathrm{CRC}$ & $\mathrm{SED}^{2}$ & Conc $^{3}$ & SEM $^{4}$ \\
\hline C12:0 & 0.04 & 0.01 & 0.03 & 0.005 & 2.35 & 1.506 \\
C14:0 & 0.07 & 0.06 & 0.08 & 0.008 & 0.98 & 0.441 \\
C16:0 & 3.52 & 3.53 & 4.43 & 0.326 & 13.9 & 1.83 \\
C16:1 n-7 & 0.34 & 0.12 & 0.04 & 0.006 & 0.16 & 0.025 \\
C18:0 & 0.25 & 0.43 & 0.55 & 0.039 & 1.66 & 0.153 \\
C18:1 n-9 & 0.48 & 0.44 & 0.61 & 0.050 & 17.6 & 1.62 \\
C18:2 n-6 & 3.22 & 5.07 & 6.11 & 0.447 & 21.1 & 0.88 \\
C18:3 n-3 & 16.5 & 13.3 & 14.7 & 1.96 & 2.10 & 0.317 \\
C20:0 & 0.08 & 0.15 & 0.21 & 0.011 & 0.19 & 0.012 \\
Total & 25.1 & 24.1 & 28.4 & 2.78 & 62.8 & 2.77 \\
\hline
\end{tabular}

${ }^{1} \mathrm{G}=$ grass; $\mathrm{RC}=$ red clover; $\mathrm{CRC}=$ conditioned red clover.

${ }^{2} \mathrm{SED}=$ standard error of the difference.

${ }^{3} \mathrm{Conc}=$ dairy concentrate.

${ }^{4}$ For SEM, $\mathrm{n}=3$.

opposite was true for total N. The PPO activity and soluble phenol concentrations were greater in the RC herbage compared with the other 2 herbages, and CRC exhibited greater levels of soluble phenols than G. Both $\mathrm{G}$ and CRC had complete PPO activation, whereas in $\mathrm{RC}$ just less than $30 \%$ of PPO was active. The CRC protein had the greatest level of bound phenol, G had the least, and $\mathrm{RC}$ had an intermediate level. The red clover diphenol PPO substrate, phaselic acid, was 16 times greater in $\mathrm{RC}$ than in $\mathrm{CRC}$ and was not observed in G. Another PPO substrate, clovamide, was only found in $\mathrm{RC}$, and chlorogenic acid was the only diphenol substrate observed in $\mathrm{G}$.

Total fatty acid content of the forages was similar although the red clovers had greater concentrations of C18:0, C18:2 n-6, and C20:0, whereas G had a greater concentration of C16:1 n-7 and C18:3 n-3 (Table 2). The CRC had the greatest concentration of most fatty acids with the exception of $\mathrm{C} 12: 0$ and $\mathrm{C} 14: 0$, which were comparable across forages, and C16:1 n-7, which was less. The concentrate fed was rich in C18:3 n-3, C18:1 n-9 and C16:0.

Total fatty acid and DMI were similar across dietary treatments along with $\mathrm{C} 16: 1 \mathrm{n}-7, \mathrm{C} 18: 1 \mathrm{n}-9$, and $\mathrm{C} 18: 3$ n-3 (Table 3). Intake of $\mathrm{C} 12: 0$ and $\mathrm{C} 14: 0$ was least in animals consuming $\mathrm{RC}$ compared with the other 2 forages, and C14:0 and C16:0 intakes were greater in CRC than in all diets. Intakes of C18:0, C18:2 n-6, and C20:0 were least in $\mathrm{G}$ compared with the other diets, and intakes of C18:0 and C20:0 were greatest in CRC-fed animals.

\section{Animal Performance and Milk Chemical Composition}

During the experimental period, animals lost, on average, $1.24 \pm 0.271 \mathrm{~kg} / \mathrm{d}$ with no difference across forage diets. Milk yield, SCC, and fat composition were also not different. Protein composition was greater in milk from animals offered red clover diets and lactose was greater in milk from G-fed animals. Milk from cows

Table 3. Dry matter $(\mathrm{kg} / \mathrm{d})$ and fatty acid intake $(\mathrm{g} / \mathrm{d})$ in cows fed the 3 forage diets

\begin{tabular}{|c|c|c|c|c|c|}
\hline Item & $\mathrm{G}^{1}$ & $\mathrm{RC}$ & $\mathrm{CRC}$ & $\mathrm{SED}^{2}$ & $P$-value \\
\hline $\mathrm{DM}$ & 18.7 & 19.6 & 18.2 & 0.747 & NS \\
\hline C12:0 & $4.76^{\mathrm{b}}$ & $4.37^{\mathrm{a}}$ & $4.84^{\mathrm{b}}$ & 0.167 & $*$ \\
\hline C14:0 & $2.90^{\mathrm{b}}$ & $2.74^{\mathrm{a}}$ & $3.31^{\mathrm{c}}$ & 0.183 & $*$ \\
\hline C16:0 & $84.3^{\mathrm{a}}$ & $87.3^{\mathrm{a}}$ & $95.5^{\mathrm{b}}$ & 4.03 & $\dagger$ \\
\hline C16:1 n-7 & 0.84 & 0.49 & 1.13 & 0.259 & NS \\
\hline C18:0 & $7.09^{\mathrm{a}}$ & $10.6^{\mathrm{b}}$ & $12.0^{\mathrm{c}}$ & 0.399 & *** \\
\hline C18:1 n-9 & 39.0 & 38.5 & 38.7 & 1.95 & NS \\
\hline C18:2 n-6 & $92.0^{\mathrm{a}}$ & $127^{\mathrm{b}}$ & $135^{\mathrm{b}}$ & 5.48 & $* * *$ \\
\hline C18:3 n-3 & 288 & 240 & 245 & 27.9 & NS \\
\hline $\mathrm{C} 20: 0$ & $1.64^{\mathrm{a}}$ & $3.00^{\mathrm{b}}$ & $3.99^{\mathrm{c}}$ & 0.198 & $* * *$ \\
\hline Total fatty acids & 541 & 540 & 569 & 37.7 & NS \\
\hline
\end{tabular}


Table 4. Milk yield (kg/d) and composition (\%) and fatty acid concentration $(\mathrm{mg} / \mathrm{mL})$ from cows fed the 3 forage $\operatorname{diets}^{1}$

\begin{tabular}{|c|c|c|c|c|c|}
\hline Item $^{2}$ & $\mathrm{G}$ & $\mathrm{RC}$ & $\mathrm{CRC}$ & $\mathrm{SED}^{3}$ & $P$-value \\
\hline Milk yield & 32.1 & 32.7 & 32.9 & 1.39 & NS \\
\hline $\mathrm{SCC}\left(\right.$ cells $\left.\times 10^{3} / \mathrm{mL}\right)$ & 65.6 & 83.8 & 64.2 & 12.77 & NS \\
\hline Protein & $3.11^{\mathrm{a}}$ & $3.18^{\mathrm{b}}$ & $3.18^{\mathrm{b}}$ & 0.016 & $* * *$ \\
\hline Lactose & $4.70^{\mathrm{b}}$ & $4.63^{\mathrm{a}}$ & $4.66^{\mathrm{a}}$ & 0.022 & * \\
\hline Fat & 3.97 & 4.00 & 3.88 & 0.157 & NS \\
\hline C12:0 & $1.12^{\mathrm{b}}$ & $1.02^{\mathrm{ab}}$ & $0.96^{\mathrm{a}}$ & 0.057 & $\dagger$ \\
\hline C14:0 & $3.21^{\mathrm{a}}$ & $4.12^{\mathrm{b}}$ & $4.13^{\mathrm{b}}$ & 0.143 & $* * *$ \\
\hline C16:0 & $10.5^{\mathrm{b}}$ & $9.28^{\mathrm{a}}$ & $9.31^{\mathrm{a}}$ & 0.415 & $*$ \\
\hline C16:1 n-7 & 0.54 & 0.44 & 0.51 & 0.042 & NS \\
\hline C18:0 & 4.18 & 3.74 & 3.77 & 0.423 & NS \\
\hline C18:1 n-9 & 8.06 & 8.14 & 8.74 & 0.504 & NS \\
\hline $\mathrm{C} 18: 1$ total cis & 8.39 & 8.53 & 9.15 & 0.517 & NS \\
\hline C18:1 total trans & 1.55 & 1.74 & 1.58 & 0.119 & NS \\
\hline C18:2 n-6 & $0.47^{\mathrm{a}}$ & $0.81^{\mathrm{b}}$ & $0.85^{\mathrm{b}}$ & 0.028 & $* * *$ \\
\hline C18:2 CLA & 0.37 & 0.37 & 0.33 & 0.047 & NS \\
\hline $\mathrm{C} 18: 2 \mathrm{NC}$ & 0.18 & 0.23 & 0.20 & 0.026 & NS \\
\hline C18:3 n-3 & $0.29^{\mathrm{a}}$ & $0.50^{\mathrm{b}}$ & $0.53^{\mathrm{b}}$ & 0.027 & $* * *$ \\
\hline C20:0 & 0.05 & 0.04 & 0.05 & 0.007 & NS \\
\hline Total SC & 1.93 & 1.78 & 1.83 & 0.077 & NS \\
\hline Total LC & $0.18^{\mathrm{a}}$ & $0.24^{\mathrm{b}}$ & $0.24^{\mathrm{b}}$ & 0.006 & $* * *$ \\
\hline Total BOC & 1.38 & 1.33 & 1.36 & 0.060 & NS \\
\hline Total fatty acids & 35.7 & 34.1 & 34.6 & 1.24 & NS \\
\hline
\end{tabular}

offered either red clover diet contained greater levels of C14:0, C18:2 n-6, C18:3 n-3, and total long-chain fatty acids than animals offered $\mathrm{G}$, whereas the opposite was true for C12:0 and C16:0 milk content (Table 4).

\section{Nitrogen Balance}

Nitrogen intake was similar between RC and CRC and less in G-fed animals. Urinary N output and milk $\mathrm{N}$ secretion were less in $\mathrm{G}$ than in either red cloverfed groups, with no effect on proportions of $\mathrm{N}$ intake. There was a tendency for greater excretion of $\mathrm{N}$ in feces of CRC- compared with G-fed animals, but there was a greater proportion of $\mathrm{N}$ intake excreted as feces in $\mathrm{G}$-fed animals. There was no effect of diet on net loss of $\mathrm{N}$ either when expressed as total (average of $33.7 \mathrm{~g} / \mathrm{d}$ ) or as a proportion of dietary $\mathrm{N}$ intake (Table 5).

\section{Forage AA Concentration, Intake, Fecal Excretion, and Apparent Whole-Tract Digestibility}

Total AA content was less in $\mathrm{G}$ than in $\mathrm{RC}$ diets, with CRC at an intermediate level. The content of individual AA, with the exception of Met, which was comparable across forages, followed the pattern: $\mathrm{G}<$
CRC $\leq \mathrm{RC}$ (Table 6). Total and individual AA intake reflected this pattern with greater intake values (with the exception of Met) for red clover herbages, with RC showing the greatest levels. The CRC-fed animals only had greater intakes of Asp, Ser, Ile, Tyr, Phe, His, and total AA than G-fed animals (Table 7).

Amino acid fecal outputs per unit of $\mathrm{N}$ intake are split into total AA (all AA as free, peptides, and proteins) and free AA and are presented in Table 8. Fecal outputs of total AA in G-fed animals were greater than in red clover-fed animals for Thr and Ala, and greater than RC-fed animals for Val, Ile, Leu, and Phe. For free AA output, G-fed animals showed greater loss than red clover-fed animals for Asp, Ala, and His and greater output than RC-fed animals for Lys. The CRC-fed animals showed the greatest loss of free AA compared with all other treatments for Thr, Ser, Glu, Val, Ile, and Leu. Values for Ala and Lys were also greater for CRC than $\mathrm{RC}$, and Tyr values were greater than in $\mathrm{G}$.

Apparent whole-tract AA digestibility presented in Table 9 shows greater apparent digestibilities for all AA, with the exception of Met, for RC- compared with G-fed animals with CRC as an intermediate. Apparent digestibility of Met was greater in $\mathrm{G}$ than either RC- or CRC-fed animals. 
LEE ET AL.

Table 5. Nitrogen intake and portioning in dairy cows fed the three forage $\operatorname{diets}^{1}$

\begin{tabular}{|c|c|c|c|c|c|}
\hline Item & $\mathrm{G}$ & $\mathrm{RC}$ & CRC & $\mathrm{SED}^{2}$ & $P$-value \\
\hline \multicolumn{6}{|l|}{ Nitrogen intake (g/d) } \\
\hline Grass & $385^{\mathrm{a}}$ & $581^{\mathrm{b}}$ & $561^{\mathrm{b}}$ & 52.5 & $*$ \\
\hline Concentrate & 56 & 56 & 56 & - & - \\
\hline Total & $441^{\mathrm{a}}$ & $637^{\mathrm{b}}$ & $618^{\mathrm{b}}$ & 52.5 & * \\
\hline \multicolumn{6}{|l|}{ Nitrogen output } \\
\hline Urine $(\mathrm{g} / \mathrm{d})$ & $168^{\mathrm{a}}$ & $279^{\mathrm{b}}$ & $277^{\mathrm{b}}$ & 23.1 & ** \\
\hline Proportion of $\mathrm{N}$ intake & 0.39 & 0.46 & 0.45 & 0.066 & NS \\
\hline Feces $(g / d)$ & $183^{\mathrm{a}}$ & $190^{\mathrm{ab}}$ & $224^{\mathrm{b}}$ & 15.4 & $\dagger$ \\
\hline Proportion of N intake & $0.45^{\mathrm{b}}$ & $0.32^{\mathrm{a}}$ & $0.37^{\mathrm{a}}$ & 0.047 & $\dagger$ \\
\hline $\operatorname{Milk}(\mathrm{g} / \mathrm{d})$ & $122^{\mathrm{a}}$ & $154^{\mathrm{b}}$ & $163^{\mathrm{b}}$ & 14.4 & $\dagger$ \\
\hline Proportion of $\mathrm{N}$ intake & 0.28 & 0.25 & 0.26 & 0.024 & NS \\
\hline Retention/loss $(\mathrm{g} / \mathrm{d})$ & -31.1 & -16.0 & -46.1 & 34.6 & NS \\
\hline Proportion of N intake & -0.12 & -0.03 & -0.08 & 0.011 & NS \\
\hline
\end{tabular}

\section{DISCUSSION}

\section{Chemical Composition and PPO Activity}

Chemical composition of the forages was as expected with greater DM, fiber, and WSC in the grass and greater total $\mathrm{N}$ in the clovers but with no difference between the red clovers. Concentration of WSC in the grass was in the upper quartile of the range described by McGrath (1988) for Italian ryegrass.

Activity of PPO for the CRC treatment was surprisingly low and comparable to the $\mathrm{G}$ treatment. This was most likely because of the proteolytic and product (quinone binding) deactivation of the enzyme as a consequence of the level of cell damage. Although deactivation of the G PPO would likely have also occurred due to proteolytic and product binding stresses, either greater cell damage, protease activity, quinone binding to the PPO enzyme, or a combination of all 3 resulted in reducing $\mathrm{PPO}$ in $\mathrm{CRC}$ to the level observed in G. Loss of PPO activity in red clover during incubation has been previously reported (Sullivan et al., 2004). The remaining PPO in CRC was in the active form with a significant depletion of the soluble phenol and an increase in the level of bound phenol compared with $\mathrm{RC}$, indicating that the PPO had catalyzed the conversion of the substrate to quinones and these had bound with protein. This was confirmed by the loss of clovamide and extensive depletion of phaselic acid, which are endogenous substrates of red clover PPO, and the black discoloration of the material. Grass PPO only exists in the active form and so, as expected, was also fully activated in the material fed (Winters et al. 2003). Less than $30 \%$ of PPO was present in an activated state in unconditioned red clover, and therefore, it was possible to compare activated red clover PPO
(CRC) against inactivated or less activated PPO (RC), or more importantly a greater level of formed phenolbound protein complexes (CRC) with a lesser level (RC). It was evident from the formation of phenolbound protein in RC at a little over $50 \%$ of CRC that harvesting and preparing the crop did result in a level of PPO activation or that there were sufficient levels of endogenous active PPO to create this effect (Lee et al., 2004; Sullivan and Hatfield, 2006; Winters et al., 2008). Likewise with the $\mathrm{G}$ treatment, the formation of phenol-bound protein, although at a concentration $16 \%$ of CRC, indicated a PPO effect. Grass PPO has been shown to be highly variable between species with levels ranging from negligible in tall fescue (Festuca arundinacea) to levels comparable to red clover in cocksfoot (Dactylis glomerata) with Italian ryegrass intermediary

Table 6. Amino acid compositions (g/100 g of DM) of the dietary forages $^{1}$

\begin{tabular}{lcccc}
\hline Item & $\mathrm{G}$ & $\mathrm{RC}$ & $\mathrm{CRC}$ & SED $^{2}$ \\
\hline Asp & 0.86 & 2.09 & 2.00 & 0.423 \\
Thr & 0.44 & 0.66 & 0.63 & 0.223 \\
Ser & 0.43 & 0.70 & 0.69 & 0.245 \\
Glu & 1.01 & 1.43 & 1.37 & 0.678 \\
Pro & 0.43 & 0.62 & 0.59 & 0.222 \\
Gly & 0.41 & 0.58 & 0.54 & 0.231 \\
Ala & 0.55 & 0.70 & 0.66 & 0.354 \\
Val & 0.49 & 0.73 & 0.67 & 0.241 \\
Met & 0.16 & 0.13 & 0.14 & 0.035 \\
Ile & 0.37 & 0.57 & 0.52 & 0.145 \\
Leu & 0.72 & 1.09 & 1.01 & 0.425 \\
Tyr & 0.18 & 0.36 & 0.33 & 0.236 \\
Phe & 0.49 & 0.70 & 0.64 & 0.300 \\
His & 0.22 & 0.38 & 0.35 & 0.247 \\
Lys & 0.56 & 0.89 & 0.83 & 0.398 \\
Arg & 0.45 & 0.66 & 0.61 & 0.312 \\
Total & 7.78 & 12.3 & 11.6 & 2.11 \\
\hline L & &
\end{tabular}

${ }^{1} \mathrm{G}=$ grass; $\mathrm{RC}=$ red clover; $\mathrm{CRC}=$ conditioned red clover.

${ }^{2} \mathrm{SED}=$ standard error of the difference. 
Table 7. Amino acid intake (g/d) of the 3 forages $^{1}$

\begin{tabular}{lccccc}
\hline Item & $\mathrm{G}$ & $\mathrm{RC}$ & $\mathrm{CRC}$ & $\mathrm{SED}^{2}$ & $P$-value \\
\hline Asp & $145^{\mathrm{a}}$ & $372^{\mathrm{b}}$ & $329^{\mathrm{b}}$ & 42.9 & $* * *$ \\
Thr & $74.4^{\mathrm{a}}$ & $118^{\mathrm{b}}$ & $104^{\mathrm{ab}}$ & 15.1 & $*$ \\
Ser & $72.7^{\mathrm{a}}$ & $125^{\mathrm{b}}$ & $113^{\mathrm{b}}$ & 15.7 & $* *$ \\
Glu & $171^{\mathrm{a}}$ & $255^{\mathrm{b}}$ & $225^{\mathrm{ab}}$ & 33.3 & $*$ \\
Pro & $72.7^{\mathrm{a}}$ & $110^{\mathrm{b}}$ & $97.0^{\mathrm{ab}}$ & 14.4 & $*$ \\
Gly & $69.3^{\mathrm{a}}$ & $103^{\mathrm{b}}$ & $88.7^{\mathrm{ab}}$ & 13.5 & $* *$ \\
Ala & $93.0^{\mathrm{a}}$ & $125^{\mathrm{b}}$ & $109^{\mathrm{ab}}$ & 16.9 & $\dagger$ \\
Val & $82.8^{\mathrm{a}}$ & $130^{\mathrm{b}}$ & $110^{\mathrm{ab}}$ & 16.7 & $*$ \\
Met & 27.0 & 23.1 & 23.0 & 3.87 & NS \\
Ile & $62.5^{\mathrm{a}}$ & $102^{\mathrm{b}}$ & $85.5^{\mathrm{b}}$ & 12.9 & $* *$ \\
Leu & $121^{\mathrm{a}}$ & $194^{\mathrm{b}}$ & $166^{\mathrm{ab}}$ & 24.8 & $* 6.64$ \\
Tyr & $30.4^{\mathrm{a}}$ & $64.1^{\mathrm{b}}$ & $54.2^{\mathrm{b}}$ & 16.2 & $* *$ \\
Phe & $82.8^{\mathrm{a}}$ & $125^{\mathrm{b}}$ & $105^{\mathrm{b}}$ & 8.34 & $* * *$ \\
His & $33.2^{\mathrm{a}}$ & $67.6^{\mathrm{b}}$ & $57.5^{\mathrm{b}}$ & 20.0 & $*$ \\
Lys & $94.6^{\mathrm{a}}$ & $158^{\mathrm{b}}$ & $136^{\mathrm{ab}}$ & 15.2 & $* *$ \\
Arg & $76.0^{\mathrm{a}}$ & $118^{\mathrm{b}}$ & $100^{\mathrm{ab}}$ & 277.0 & $* *$ \\
Total & $1,315^{\mathrm{a}}$ & $2,189^{\mathrm{b}}$ & $1,906^{\mathrm{b}}$ & & $* *$ \\
\hline
\end{tabular}

a,b Differing superscript letters within a row denote significance at $\dagger P<0.1 ;{ }^{*} P<0.05 ;{ }^{* *} P<0.01 ; * * *<$ $0.001 ;$ NS $P>0.1$.

${ }^{1} \mathrm{G}=$ grass; $\mathrm{RC}=$ red clover; $\mathrm{CRC}=$ conditioned red clover.

${ }^{2} \mathrm{SED}=$ standard error of the difference.

between the two (Lee et al., 2006). Grass PPO, despite having properties distinct from red clover PPO, such as substrate (chlorogenic acid, caffeoyl isocitrate), lack of latent form, and different $\mathrm{pH}$ optima, have been shown to have similar effects in reducing proteolysis (Winters et al., 2003; Lee et al., 2006) and lipolysis (Lee et al., 2006). On the other hand, Marita et al. (2005) reported that due to a lack of substrate in grasses, the effect of PPO in reducing proteolysis was minimal. This dichotomy between studies may indicate fluctuations in diphenol concentration in grasses across regions and seasons, and calls for more research into the potential of grass PPO.

\section{Fatty Acid Intake and Milk Composition}

Intakes of DM and total fatty acids were similar across diets and were greater compared with other

Table 8. Fecal output of total (TAA) and free amino acids (FAA) per unit $\mathrm{N}$ intake from animals offered the 3 forage diets ${ }^{1}$

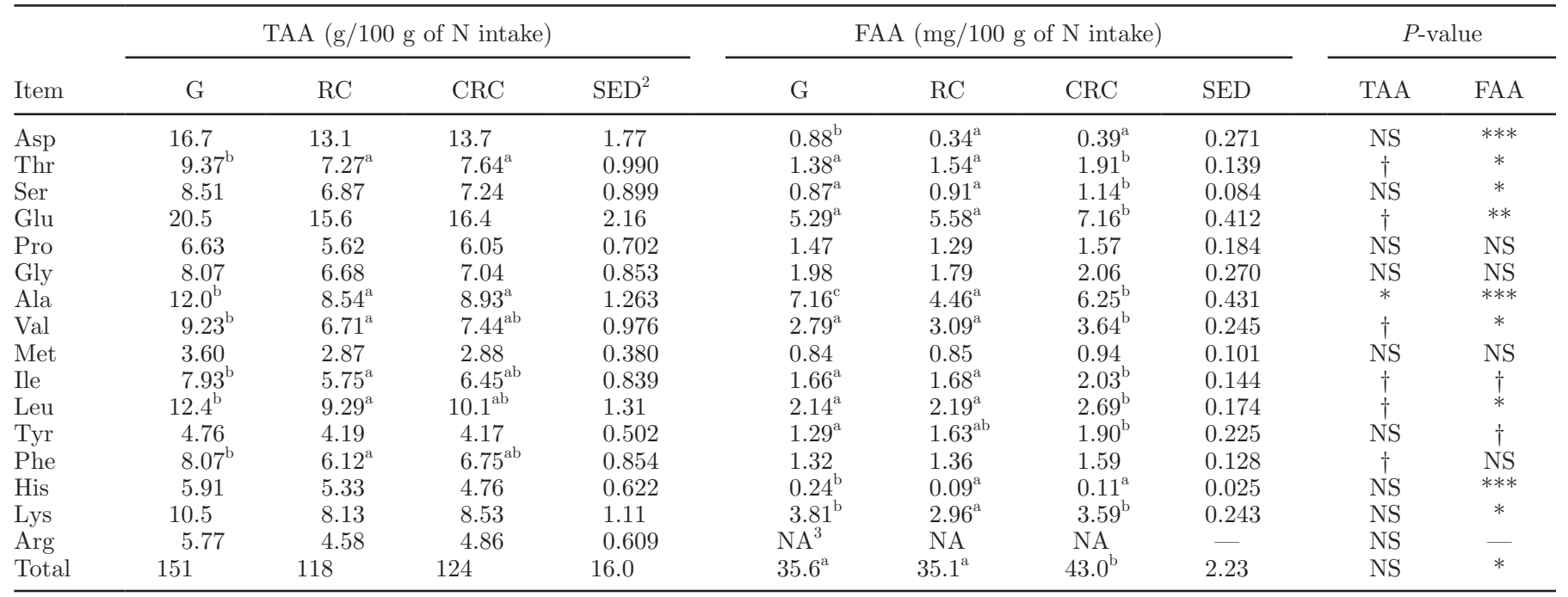

${ }^{\mathrm{a}-\mathrm{c}}$ Differing superscript letters within a row and within total or free AA columns, respectively, denote significance at $\dagger P<0.1 ; * P<0.05 ; * * * P$ $<0.001 ;$ NS $P>0.1$.

${ }^{1} \mathrm{G}=$ grass; $\mathrm{RC}=$ red clover; $\mathrm{CRC}=$ conditioned red clover.

${ }^{2} \mathrm{SED}=$ standard error of the difference.

${ }^{3} \mathrm{NA}=$ cannot be assessed by GC because of its polar nature. 
LEE ET AL.

Table 9. AA apparent whole-tract digestibility (intake - fecal output/intake) of the 3 forages ${ }^{1}$

\begin{tabular}{|c|c|c|c|c|c|}
\hline Item & G & $\mathrm{RC}$ & CRC & $\mathrm{SED}^{2}$ & $P$-value \\
\hline Asp & $0.55^{\mathrm{a}}$ & $0.78^{\mathrm{b}}$ & $0.74^{\mathrm{b}}$ & 0.027 & $* * *$ \\
\hline Thr & $0.51^{\mathrm{a}}$ & $0.62^{\mathrm{b}}$ & $0.55^{\mathrm{a}}$ & 0.028 & $* *$ \\
\hline Ser & $0.54^{\mathrm{a}}$ & $0.66^{\mathrm{b}}$ & $0.61^{\mathrm{b}}$ & 0.026 & * \\
\hline Glu & $0.53^{\mathrm{a}}$ & $0.62^{\mathrm{b}}$ & $0.55^{\mathrm{a}}$ & 0.027 & $* *$ \\
\hline Pro & $0.64^{\mathrm{ab}}$ & $0.68^{\mathrm{b}}$ & $0.62^{\mathrm{a}}$ & 0.020 & $\dagger$ \\
\hline Gly & $0.54^{\mathrm{a}}$ & $0.60^{\mathrm{b}}$ & $0.51^{\mathrm{a}}$ & 0.026 & $* * *$ \\
\hline Ala & $0.50^{\mathrm{a}}$ & $0.58^{\mathrm{b}}$ & $0.49^{\mathrm{a}}$ & 0.029 & $* * *$ \\
\hline Val & $0.56^{\mathrm{a}}$ & $0.68^{\mathrm{b}}$ & $0.59^{\mathrm{a}}$ & 0.025 & $* *$ \\
\hline Met & $0.48^{\mathrm{b}}$ & $0.24^{\mathrm{a}}$ & $0.23^{\mathrm{a}}$ & 0.031 & $* * *$ \\
\hline Ile & $0.50^{\mathrm{a}}$ & $0.65^{\mathrm{b}}$ & $0.54^{\mathrm{a}}$ & 0.028 & $* *$ \\
\hline Leu & $0.60^{\mathrm{a}}$ & $0.70^{\mathrm{b}}$ & $0.63^{\mathrm{a}}$ & 0.023 & $* *$ \\
\hline Tyr & $0.39^{\mathrm{a}}$ & $0.59^{\mathrm{b}}$ & $0.53^{\mathrm{b}}$ & 0.035 & $* * *$ \\
\hline Phe & $0.62^{\mathrm{a}}$ & $0.70^{\mathrm{b}}$ & $0.61^{\mathrm{a}}$ & 0.021 & $* *$ \\
\hline His & $0.38^{\mathrm{a}}$ & $0.51^{\mathrm{b}}$ & $0.49^{\mathrm{b}}$ & 0.036 & $* * *$ \\
\hline Lys & $0.56^{\mathrm{a}}$ & $0.68^{b}$ & $0.62^{\mathrm{b}}$ & 0.025 & $*$ \\
\hline Arg & $0.70^{\mathrm{a}}$ & $0.76^{\mathrm{b}}$ & $0.70^{\mathrm{a}}$ & 0.017 & $* *$ \\
\hline Total & $0.55^{\mathrm{a}}$ & $0.67^{\mathrm{C}}$ & $0.60^{\mathrm{b}}$ & 0.026 & $* * *$ \\
\hline
\end{tabular}

${ }^{\text {a } c}$ Differing superscript letters within a row denote significance at $\dagger P<0.1 ;{ }^{*} P<0.05$; ${ }^{* *} P<0.01$; ${ }^{* * *} P<$ $0.001 ; \mathrm{NS} P>0.1$.

${ }^{1} \mathrm{G}=$ grass $; \mathrm{RC}=$ red clover CRC $=$ conditioned red clover.

${ }^{2} \mathrm{SED}=$ standard error of the difference.

studies where cut forage has been offered (Miller et al., 2001; Van Dorland et al., 2008) but are supported by the high milk yield achieved, which averaged $32.6 \mathrm{~kg} / \mathrm{d}$ across treatments. Because of composition differences of the forages, cows offered red clover consumed more C18:0 and C18:2 n-6 than cows offered the control G. The greater intake of saturated fatty acids in the CRC versus the RC treatments is also an effect of compositional differences, as wilting has been shown to increase saturated fatty acid concentration in forages as a result of DM losses (Dewhurst and King, 1998). However, this is usually combined with loss of PUFA because of oxidation during wilting, which was not observed in the present study.

Milk C18 and long-chain PUFA concentrations were greater in milk from animals fed the red clover forages compared with $\mathrm{G}$ but were not different between $\mathrm{RC}$ and CRC. As previous studies with silage have indicated (Dewhurst et al., 2003; Al-Mabruk et al., 2004; Vanhatalo et al., 2007), red clover resulted in a significant protection of C18 PUFA across the rumen with subsequently a greater concentration in animal product (milk) compared with grass. This study confirms that the feeding of cut (fresh) as well as conserved (silage) red clover can result in a PPO protection of glycerolbased lipid, as also indicated recently by Van Dorland et al. (2008). Vanhatalo et al. (2007) postulated that this protection of C18 PUFA in red clover diets was a result of a combined effect of PPO protection and altered digestion kinetics, with a greater rate of ruminal digestion of fiber for red clover as opposed to grass silage. This would suggest a reduction in ruminal retention time resulting in a greater proportion of dietary lipids escaping metabolism in the rumen. This mechanism has been postulated for the elevated level of C18 PUFA in milk observed from white clover silage compared with grass silage (Dewhurst et al., 2003; Van Dorland et al., 2008). It may also explain in the present study the lack of difference between CRC and RC, which would likely have similar digestion kinetics. However, a previous study has reported that the fiber content and rates of passage of red clover and grass silage were comparable (Dewhurst et al., 2003), which questions the postulation of the effect being solely related to digestion kinetics. Therefore, the similarity between RC and CRC may be related to activation of $\mathrm{PPO}$ of $\mathrm{RC}$ during mastication so that the protein and lipid were as protected as the already activated CRC. Such activation in bolus material has been reported by this laboratory (Lee et al., 2008c), although greatest protection of lipid was achieved in boluses that had received a prior wilt. In the present study the activation procedure might have altered the way PPO protected the protein and lipid, as little is known about how maceration alters PPO action. For example, a slow cell damage procedure such as wilting may result in a gradual diphenol oxidation that could favor nucleophilic coupling of quinones to proteins, followed by oxidative crosslinking of the diphenol-protein complexes, forming tightly complexed low solubility protein. Such crosslinking would protect proteins from the action of plant proteases by denaturing of plant proteases through quinone binding, and microbial proteases by complexing of plant protein, reducing solubility (Winters and Minchin, 2001). In contrast, 
a more severe cell damage such as cutting and crushing followed by chilling as with CRC may have resulted in a more rapid oxidation of diphenols, favoring coupling of quinones with proteins at the expense of continued coupling reactions to crosslink diphenol-protein complexes (Grabber, 2008). Under this scenario the protein would be protected from plant proteases, because these would be denatured through phenol binding, but only partially from microbial proteases, because there would be less tightly complexed protein. Such questions regarding mechanisms highlight the need for further research into the action of red clover in improving C18 PUFA in ruminant products.

\section{Nitrogen Use Efficiency}

Nitrogen intake was greater on the red clover diets than the grass diets and this resulted in greater levels of protein in milk and $\mathrm{N}$ in milk, urine, and feces, although no difference was found between the 2 red clover diets, probably because of the reasons discussed previously. Proportions of $\mathrm{N}$ intake partitioning into milk and urine were not different across diets and are in the range expected with lactating dairy cows (Brito and Broderick, 2007). Nevertheless, the current results contradict the findings of Dewhurst et al. (2003) who compared red clover silage with grass or white clover silages and found a greater portioning of dietary $\mathrm{N}$ partitioning into product (milk and retained) when red clover silage was fed. The results in the current study may have been because of the large level of WSC in the grass resulting in an elevation in the $\mathrm{N}$ use efficiency of the grass diet as a consequence of the greater balance of $\mathrm{N}$ and energy in the rumen (Miller et al., 2001; Lee et al., 2002). However, previous studies with red clover silage have also failed to show an elevation in $\mathrm{N}$ use efficiency compared with grass or white clover silages (Bertilsson and Murphy, 2003; Van Dorland et al., 2006, 2007). The variation in the response to red clover across different studies is associated with the amount of $\mathrm{N}$ going into the system. Poppi and McLennan (1995) reported that net transfer of feed protein to the intestines is often not complete, and losses occur in grasses and legumes when CP content exceeds $210 \mathrm{~g} / \mathrm{kg}$ of digestible OM. In the present study these values were 152,225 , and 229 $\mathrm{g}$ of $\mathrm{CP} / \mathrm{kg}$ of $\mathrm{OM}$ for $\mathrm{G}, \mathrm{RC}$, and $\mathrm{CRC}$, respectively. Therefore, any advantage in $\mathrm{N}$ use efficiency inferred by the red clover PPO was lost due to the excessive $\mathrm{N}$ input. Castillo et al. (2000) reported that reducing N pollution in urine by $66 \%$ could be achieved by lowering CP intake from 200 to $150 \mathrm{~g} / \mathrm{kg}$ of DM. This compares with values of 138,203 , and $207 \mathrm{~g} / \mathrm{kg}$ of $\mathrm{DM}$ for $\mathrm{G}, \mathrm{RC}$, and CRC, respectively, and highlights the potential to reduce $\mathrm{N}$ excretion below that of $\mathrm{G}$ using red clover if $\mathrm{N}$ intake could be reduced.

\section{AA Intake, Fecal Output and Apparent Whole-Tract Digestibility}

Intake of all AA, with the exception of Met for which there was no difference across treatments, was greater on $\mathrm{RC}$ than $\mathrm{G}$ with CRC intermediate, as a consequence of the AA composition of the forages. Differences between red clovers were small and may be related to oxidative losses of AA during preparation of CRC. Total fecal AA per unit of $\mathrm{N}$ intake was not different across treatments, although certain individual AA were greater on $\mathrm{G}$ than $\mathrm{RC}$ diets relating to their lower apparent wholetract digestibilities. Apparent whole-tract digestibilities are less than the absorption coefficients reported in the review by MacRae et al. (1995), because of the contribution to the fecal AA pool made by the large intestine, and must be interpreted with this in mind. However, they do indicate the greater net absorption of AA (with the exception of Met) on the red clover diet, possibly as a consequence of the protein protective qualities of PPO. However, comparison across different forage species (grass vs. red clover) produces numerous other confounding factors other than PPO, such as $\mathrm{N}$ content and digestibility. Studies with genetically modified material where gene activity is silenced may offer solutions to these problems (Sullivan et al., 2004). Differences between RC and CRC in apparent wholetract AA digestibility and free AA loss in feces may be related to differences in protein protection conferred by PPO as previously discussed.

The current study shows a lower apparent whole-tract digestibility of Met after consumption of red clover as opposed to G. Although total and free Met in feces per unit of $\mathrm{N}$ intake were comparable across treatments, $\mathrm{G}$ is shown to have a greater intake of Met compared with either RC or CRC $(7.0,4.0$, and $4.1 \mathrm{~g}$ of Met intake/100 $\mathrm{g}$ of $\mathrm{N}$ intake for $\mathrm{G}, \mathrm{RC}$, and $\mathrm{CRC}$, respectively) when intake is reported in the same units, and the greater loss on the red clover diets becomes apparent. Methionine and Lys are the 2 most limiting AA in most ruminant diets (Donkin et al., 1989). Methionine has been identified as the first-limiting AA in growing steer calves (Richardson and Hatfield, 1978) and is also limiting in growing lambs (Storm and Orskov, 1984), and is also the most predominant AA for fleece and hair growth. Therefore, more detailed digesta flow measurements are required to confirm the reduction in Met digestibility in response to red clover feeding, because of the confounding factors with whole-tract digestibility measurements from feces that complicate this study. 


\section{CONCLUSIONS}

Offering red clover to dairy cows as opposed to grass resulted in greater concentrations of C18 PUFA and protein in milk but did not improve $\mathrm{N}$ use efficiency. Fully activating PPO before offering the red clover had no effect on either milk PUFA or N use efficiency and highlights the need for more research into the mechanism of PPO in the rumen. The potential to increase $\mathrm{N}$ use efficiency was lost because of the excessive supply of $\mathrm{N}$ in the red clover diet, which shows the potential to breed forages with PPO activity and lesser $\mathrm{N}$ contents.

\section{ACKNOWLEDGMENTS}

This work was funded by the Department for the Environment, Food, and Rural Affairs of the British Government. The authors thank and acknowledge Jon Moorby [Institute of Biological, Environmental and Rural Sciences (IBERS), Aberystwyth University] for help with the design, Naomi Ellis and Martin Leyland (IBERS) for the care of the animals, Sue Lister and her staff in analytical chemistry (IBERS) for the chemical composition data, Dan Dhanoa (IBERS) for his statistical expertise, and the valuable discussion with A. M. Mayer of The Hebrew University of Jerusalem on quinone AA binding.

\section{REFERENCES}

Akagawa, M., T. Shigemitsu, and K. Suyama. 2005. Oxidative deamination of benzylamine and lysine residue in bovine serum albumin by green tea, black tea and coffee. J. Agric. Food Chem. 53:8019-8024.

Al-Mabruk, R. M., N. F. G. Beck, and R. J. Dewhurst. 2004. Effects of silage species and supplemental vitamin $\mathrm{E}$ on the oxidative stability of milk. J. Dairy Sci. 87:406-412.

Albrecht, K. A., and G. A. Broderick. 1992. Ruminal in vitro degradation of protein from different legume species. Pages 92-94 in Res. Summ., USDA Forage Res. Center. Madison, WI.

Albrecht, K. A., and R. E. Muck. 1991. Proteolysis in ensiled forage legumes that vary in tannin concentration. Crop Sci. 31:464469 .

Alder, E., and R. Magnusson. 1959. Treated methylcatechol with equimolar concentrated sodium periodate produces quinine product. Acta Chem. Scand. 13:505-519.

Ashton, K., W. J. Fisher, A. B. McAllan, M. S. Dhanoa, and R. J. Dewhurst. 1998. Supplementation of grass silage-based diets with small quantities of concentrates: Strategies for allocating concentrate crude protein. Anim. Sci. 67:17-26.

Beever, D. E., M. S. Dhanoa, H. R. Losada, R. T. Evans, S. B Cammell, and J. France. 1986. The effect of forage species and stage of harvest on the processes of digestion occuring in the rumen of cattle. Br. J. Nutr. 56:439-454.

Bertilsson, J., and M. Murphy. 2003. Effects of feeding clover silages on feed intake, milk production and digestion in dairy cows. Grass Forage Sci. 58:309-322.

Brito, A. F., and G. A. Broderick. 2007. Effects of different protein supplements on milk production and nutrient utilization in lactating dairy cows. J. Dairy Sci. 90:1816-1827.
Brito, A. F., R. J. Dewhurst, and R. Berthiaume. 2008. N partitioning study with dairy cows fed red clover silage: Unaccounted losses. Page R09 in Can. Soc. Anim. Sci., Guelph, Canada.

Castillo, A. R., E. Kebreab, D. E. Beever, and J. France. 2000. A review of efficiency of nitrogen utilisation in lactating dairy cows and its relationship with environmental pollution. J. Anim. Feed Sci. 9:1-32.

Cochran, W. G., and G. M. Cox. 1957. Experimental Designs. 2nd ed. John Wiley and Sons, Chichester, UK.

Dewhurst, R. J., R. T. Evans, N. D. Scollan, J. M. Moorby, R. J. Merry, and R. J. Wilkins. 2003. Comparison of grass and legume silages for milk production. 2. In vivo and in sacco evaluations of rumen function. J. Dairy Sci. 86:2612-2621.

Dewhurst, R. J., and P. J. King. 1998. Effects of extended wilting, shading and chemical additives on the fatty acids in laboratory grass silages. Grass Forage Sci. 53:219-224.

Dewhurst, R. J., A. M. Mitton, N. W. Offer, and C. Thomas. 1996. Effects of the composition of grass silages on milk production and nitrogen utilisation by dairy cows. Anim. Sci. 62:25-34.

Donkin, S. S., G. A. Varga, T. F. Sweeney, and L. D. Muller. 1989. Rumen-protected methionine and lysine: Effects on animal performance, milk protein yield, and physiological measures. J. Dairy Sci. 72:1484-1491.

Grabber, J. H. 2008. Mechanical maceration divergently shifts protein degradability in condensed-tannin vs. o-quinone containing conserved forages. Crop Sci. 48:804-813.

Igarashi, K., and T. Yasui. 1985. Oxidation of free methionine and methionine residues in protein involved in the browning reaction of phenolic compounds. Agric. Biol. Chem. 49:2309-2315.

Jones, B. A., R. E. Muck, and R. D. Hatfield. 1995. Red clover extracts inhibit legume proteolysis. J. Sci. Food Agric. 67:329-333.

Lee, M. R. F., L. J. Harris, J. M. Moorby, M. O. Humphreys, M. K. Theodorou, J. C. MacRae, and N. D. Scollan. 2002. Rumen metabolism and nitrogen flow to the small intestine in steers offered Lolium perenne containing different levels of water-soluble carbohydrate. Anim. Sci. 74:587-596.

Lee, M. R. F., J. J. Olmos Colmenero, A. L. Winters, N. D. Scollan, and F. R. Minchin. 2006. Polyphenol oxidase activity in grass and its effect on plant-mediated lipolysis and proteolysis of Dactylis glomerata (cocksfoot) in a simulated rumen environment. J. Sci. Food Agric. 86:1503-1511.

Lee, M. R. F., L. J. Parfitt, N. D. Scollan, and F. R. Minchin. 2007. Lipolysis in red clover with different polyphenol oxidase activities in the presence and absence of rumen fluid. J. Sci. Food Agric. 87:1308-1314.

Lee, M. R. F., M. B. Scott, J. K. S. Tweed, F. R. Minchin, and D. R. Davies. 2008a. Effects of polyphenol oxidase on lipolysis and proteolysis of red clover silage with and without a silage inoculant (Lactobacillus plantarum L54). Anim. Feed Sci. Technol. 144:125136.

Lee, M. R. F., and J. K. S. Tweed. 2008. Isomerisation of cis-9 trans-11 conjugated linoleic acid (CLA) to trans-9 trans-11 CLA during acidic methylation can be avoided by a rapid base catalysed methylation of milk fat. J. Dairy Res. 75:354-356.

Lee, M. R. F., J. K. S. Tweed, F. R. Minchin, and A. L. Winters. 2008c. Red clover polyphenol oxidase: Activation, activity and efficacy under grazing. Anim. Feed Sci. Technol. doi:10.1016/j. anifeedsci.2008.06.013.

Lee, M. R. F., J. K. S. Tweed, A. P. Moloney, and N. D. Scollan. 2005. The effects of fish oil supplementation on rumen metabolism and the biohydrogenation of unsaturated fatty acids in beef steers given diets containing sunflower oil. Anim. Sci. 80:361-367.

Lee, M. R. F., J. K. S. Tweed, N. D. Scollan, and M. L. Sullivan, 2008b. Mechanism of polyphenol oxidase in reducing lipolysis and proteolysis in red clover during batch culture incubation. Page 31 in Proc. Br. Soc. Anim. Sci., Scarborough, UK.

Lee, M. R. F., A. L. Winters, N. D. Scollan, R. J. Dewhurst, M. K. Theodorou, and F. R. Minchin. 2004. Plant-mediated lipolysis and proteolysis in red clover with different polyphenol oxidase activities. J. Sci. Food Agric. 84:1639-1645. 
MacRae, J. C., L. A. Bruce, and D. S. Brown. 1995. Efficiency of utilization of absorbed amino acids in growing lambs given forage and forage: barley diets. Anim. Sci. 61:277-284.

Marita, J. M., R. D. Hatfield, and G. E. Brink. 2005. Polyphenol oxidase activity and in vitro proteolytic inhibition in grasses. Page 220 in 20th Int. Grassl. Conf., Dublin, Rep. Ireland.

McGrath, D. 1988. Seasonal variation in the water-soluble carbohydrates of perennial and Italian ryegrass under cutting conditions. Ir. J. Agric. Res. 27:131-139.

Miller, L. A., J. M. Moorby, D. R. Davies, M. O. Humphreys, N. D. Scollan, J. C. MacRae, and M. K. Theodorou. 2001. Increased concentration of water-soluble carbohydrate in perennial ryegrass (Lolium perenne L.): Milk production from late-lactation dairy cows. Grass Forage Sci. 56:383-394.

Poppi, D. P., and S. R. McLennan. 1995. Protein and energy utilization by ruminants at pasture. J. Anim. Sci. 73:278-290.

Richardson, C. R., and E. E. Hatfield. 1978. The limiting amino acids in growing cattle. J. Anim. Sci. 46:740-745.

Robert, C. M., F. R. Cadet, C. C. Rouch, M. Pabion, and F. RichardForget. 1995. Kinetic study of the irreversible thermal deactivation of palmito (Acanthophoenix rubra) polyphenol oxidase and effect of pH. J. Agric. Food Chem. 43:1143-1150.

Rouet-Mayer, M. A., J. Philippon, and J. Nocholas. 1993. Enzymatic browning. Pages 499-510 in Encyclopedia of Food Science, Food Technology and Nutrition. R. McRae, R.K. Robinson, and M. J. Sadler, ed. Academic Press, London, UK.

Storm, E., and E. R. Orskov. 1984. The nutritive value of rumen microorganisms in ruminants. 4. The limiting amino acids of microbial protein in growing sheep determined by a new approach. Br. J. Nutr. 52:613-620.

Sukhija, P. S., and D. L. Palmquist. 1988. Rapid method for determination of total fatty acid content and composition of feedstuffs and feces. J. Agric. Food Chem. 36:1202-1206.

Sullivan, M. L., and R. D. Hatfield. 2006. Polyphenol oxidase and o-diphenol inhibits postharvet proteolysis in red clover and alfalfa. Crop Sci. 46:662-670.

Sullivan, M. L., R. D. Hatfield, S. L. Thoma, and D. A. Samac. 2004. Cloning and characterisation of red clover polyphenol oxidase cDNAs and expression of active protein in Escherichia coli and alfalfa. Plant Physiol. 136:3234-3244.
Thomas, T. A. 1977. An automated procedure for the determination of soluble carbohydrates in herbage. J. Sci. Food Agric. 28:639642

Van Dorland, H. A., M. Kreuzer, H. Leuenberger, and H.-R. Wettstein. 2008. Comparative potential of white and red clover to modify the milk fatty acid profile of cows fed ryegrass-based diets from zerograzing and silage systems. J. Sci. Food Agric. 88:77-85.

Van Dorland, H. A., H.-R. Wettstein, H. Leuenberger, and M. Kreuzer. 2006. Comparison of fresh and ensiled white and red clover added to ryegrass on energy and protein utilization of lactating cows. Anim. Sci. 82:691-700.

Van Dorland, H. A., H.-R. Wettstein, H. Leuenberger, and M. Kreuzer. 2007. Effect if supplementation of fresh and ensiled clover to ryegrass on nitrogen loss and methane emission of dairy cows. Livest. Sci. 111:57-69.

Van Soest, P. J., J. B. Robertson, and B. A. Lewis. 1991. Methods for dietary fiber, neutral detergent fiber, and nonstarch polysaccharides in relation to animal nutrition. J. Dairy Sci. 74:3568-3597.

Vanhatalo, A., K. Kuoppala, V. Toivonen, and K. J. Shingfield. 2007. Effects of forage species and stage of maturity on bovine milk fatty acid composition. Eur. J. Lipid Sci. Technol. 109:856-867.

Winters, A. L., and F. R. Minchin. 2001. Red clover and the future for pasture legumes as an alternative protein source for ruminants. Inst. Grassl. Environ. Res. Innov. 5:30-33.

Winters, A. L., and F. R. Minchin. 2005. Modification of the Lowry assay to measure proteins and phenols in covalently bound complexes. Anal. Biochem. 346:43-48.

Winters, A. L., F. R. Minchin, R. J. Merry, and P. Morris. 2003. Comparison of polyphenol oxidase activity in red clover and perennial ryegrass. Asp. Appl. Biol. 70:121-128.

Winters, A. L., F. R. Minchin, T. P. T. Michaelson-Yates, M. R. F. Lee, and P. Morris. 2008. Latent and active polyphenol oxidase (PPO) in red clover (Trifolium pratense) and use of a low PPO mutant to study the role of PPO in proteolysis reduction. J. Agric. Food Chem. 56:2817-2824 